\title{
Assessment of the impact of heavy metals in sediments along the Spanish Mediterranean coastline: Pollution Indices.
}

Maria Paches ${ }^{1}$, Remedios Martínez-Guijarro*2, Daniel Aguado ${ }^{1}$, Jose Ferrer ${ }^{1}$

1. CALAGUA - Unidad Mixta UV-UPV, Institut Universitari d'Investigació d'Enginyeria de l'Aigua i Medi Ambient - IIAMA, Universitat Politècnica de València, Camí de Vera s/n, 46022 Valencia, Spain.

2. GEIA - Institut Universitari d'Investigació d'Enginyeria de l'Aigua i Medi Ambient - IIAMA, Universitat Politècnica de València, Camí de Vera s/n, 46022 Valencia, Spain.

*Corresponding author: mmarting@hma.upv.es

\begin{abstract}
A comprehensive study was carried out to evaluate the occurrence, significance of concentrations and spatial distribution of heavy metals $(\mathrm{Cr}, \mathrm{Cd}, \mathrm{Ni}, \mathrm{Cu}, \mathrm{Pb}, \mathrm{Hg}, \mathrm{Zn}$ and $\mathrm{As})$ in sediments along the Valencia coastline (Spain). The sampling campaign covered $476 \mathrm{~km}$ of the coastline in a 4-year period. The highest concentrations of metals in the sediments were mainly $\mathrm{Cr}, \mathrm{Ni}, \mathrm{Zn}$ and $\mathrm{Cd}$ (up to $28.93 \mathrm{mg} \mathrm{Cr} \mathrm{kg}^{-1} \mathrm{dw}$, $15.80 \mathrm{mg} \mathrm{Ni} \mathrm{kg}{ }^{-1} \mathrm{dw}, 57.13 \mathrm{mg} \mathrm{Zn} \mathrm{kg}^{-1} \mathrm{dw}$ and $0.293 \mathrm{mg} \mathrm{Cd} \mathrm{kg}^{-1} \mathrm{dw}$ ), obtained in the northern areas, some central areas and in an isolated area on the southern coastline. The Sediment Quality Guidelines applied reveal that for all metals studied, none of them reached, or exceed, the "effects of median range" or the "probable effect level". The Pollution index reveals that $75 \%$ of the stretch coastline has a low priority risk level and the rest "medium-low priority risk level". And, lastly Potential Ecological Risk index shows that all but one zone have low ecological risk.
\end{abstract}

\section{Keywords}

Heavy metals; Sediment pollution; Risk assessment; Ecological Risk Indices; Background Enrichment Indices; Environmental impact; Pollution effects 


\section{Introduction}

The presence of heavy metals in the environment is attracting growing interest from researches and the community because of the toxicity, persistence and accumulation of these metals in the environment and aquatic habitats (Fachinelli et al. 2001; Loska and Wiechula 2003; Upadhyay et al. 2006; Zhou et al. 2008). Heavy metals represent a threat to natural habitats, in both the long and short term, with toxic and chronic effects on organisms that can lead to loss of biodiversity in the ecosystems affected (Johnston and Roberts 2009).

The presence of these pollutants in aquatic ecosystems is due to both natural processes (i.e. rock weathering coastal and seabed erosion) and human activities, like population growth, industrial developments, harbour expansions, tourism-related activities on the coast, discharge of inadequately treated municipal and industrial wastewater, and numerous recreational and commercial activities (Yalcin et al. 2009; Hosono et al. 2010).

Heavy metals enter aquatic systems by natural and anthropogenic pathways such as rivers, urban and industrial waste dumping, atmospheric particulate deposition, coastal and seafloor erosion, after which the sediments act as a metal accumulation repository (Leivouri 1998; lp et al. 2007; Li et al. 2013).

The low solubility metals transported into aquatic ecosystems are quickly fixed on the solid material in suspension, (Förstner and Wittman 1981) which is ultimately deposited in the sediments, which thus act as a store of metals with concentrations of several orders of magnitude higher than those of the adjacent interstitial and overlying waters.

The release of heavy metals into the environment has a great impact on aquatic systems and affects the entire food chain from the producer to the consumer (Badri and Aston 1983; Luoma 1990;

Christophorides et al. 2009).

Several heavy metals have been assigned to the priority list in European legislation, and limit values have been proposed for the protection of endangered habitats. The first Priority Substances Directive (Directive 2008/105/EC) set environmental quality standards (EQS) for substances in surface waters and made it possible to apply EQS to sediment and biota instead of those for water. A later proposal (Directive 2013/39/EU) recognised the need to improve the efficiency of monitoring campaigns. Monitoring of sediment has thus become essential for environmental assessment of heavy metal pollution. This 
assessment requires data from the sediments themselves, since the low metal concentrations and high salinity values in the water column could interfere with analytical methods (Rainbow 1995).

As the accumulation of metals in the sediment poses a long term threat to water bodies and other areas of the environment, there is a need for sediment quality indicators to assess the risks of contamination and toxicity by metals in the aquatic environment. Numerous Sediment Quality Guidelines (SQGs) have been compiled to assess metal contamination and deal with environmental concerns. SQGs are useful for screening sediment contamination by comparing contaminant concentrations with the appropriate quality guideline. The guidelines evaluate the degree to which the sediment-associated chemical status might adversely affect aquatic organisms and are designed to assist sediment assessors and managers responsible for the interpretation of sediment quality (Wenning and Ingersoll 2002).

Heavy metal pollution in a given area can also be assessed by tools such as pollution indices (Pejman et al. 2010). Caeiro et al. 2005, classified pollution indices into three types: Contamination Indices, Background Enrichment Indices and Ecological Risk Indices. Contamination indices compare the contaminants with clean and/or polluted stations measured in the study area or simply add the total metal concentrations, Background Enrichment Indices compare the results for the contaminants with different baseline or background levels, and Ecological Risk Indices compare the results for the contaminants with SQGs or Values.

The use of these SQG is world widely applied. In the Mediterranean systems the SQGs have been used to assess the ecotoxicological sense of metal concentration in sediments for example in The Bahiret el Bibane lagoon in Tunisia (Barhoumi et al. 2017), in the Bay and the Gulf of Thessaloniki, Northwester part of the Aegean Sea, (Christophoridis et al. 2009), or in the Tigris River (Turkey) (Varol 2011). In Spain, SQGs have been applied to identify zones according to their sediment quality in the Bay of Santander (north of Spain) (Alvarez-Guerra 2007) or in the Atlantic coast (Riba et al. 2009). In the Valencia coastal region previous research on chemical composition or heavy metal contents on sediments had been carried out (Lopez 1986; Sanchiz et al. 2000). Although the researches are valuable none of them taken into account the whole stretch coastline nor apply SGQ to predict adverse biological effects in contaminated sediments. In addition, heavy metals levels in commercial ports located along the Spanish coast have also been studied but none of those ports are from Valencia region (Casado-Martínez 2009). 
As to our knowledge there has not yet been a prior exhaustive impact assessment of heavy metals in the sediments along the Spanish Mediterranean coastline in Valencia. The objectives of this study were: (1) to analyse the heavy metal content $(\mathrm{Cr}, \mathrm{Cd}, \mathrm{Ni}, \mathrm{Pb}, \mathrm{Cu}, \mathrm{Hg}, \mathrm{Zn}$ and a metalloid $\mathrm{As})$ in Valencia coastal sediments; (2) to identify the source of the anthropogenic impact; (3) to assess the contamination of heavy metals in surface sediments in the area according to the Sediment Quality Guidelines (SQGs) and two Ecological Risk Indices (Mean Effects Range Median quotient (MERMQ) and three Background Enrichment Indices (Potential Ecological Risk Index, Pollution Load Index, modified Degree of Contamination).

\section{Material and Methods}

\section{Study area}

The study was carried out along the Valencia coastline, which is $476 \mathrm{~km}$ long (Fig 1). The study area includes leisure areas, which bear intensive maritime traffic, and popular tourist areas. The coastline is also affected by the large agriculture and industrial sectors in the region.

This coastline, which combines areas of great ecological value with highly anthropized areas (GVA, 2009), was divided into several zones on a holistic basis (coastal water zones and port zones, Fig. 1).

Annual mean salinity value, coastal geomorphology, coastal transport services, prevailing winds, rainfall, fluvial areas, continental inputs and wetland zones were taken into account (Romero et al. 2013).

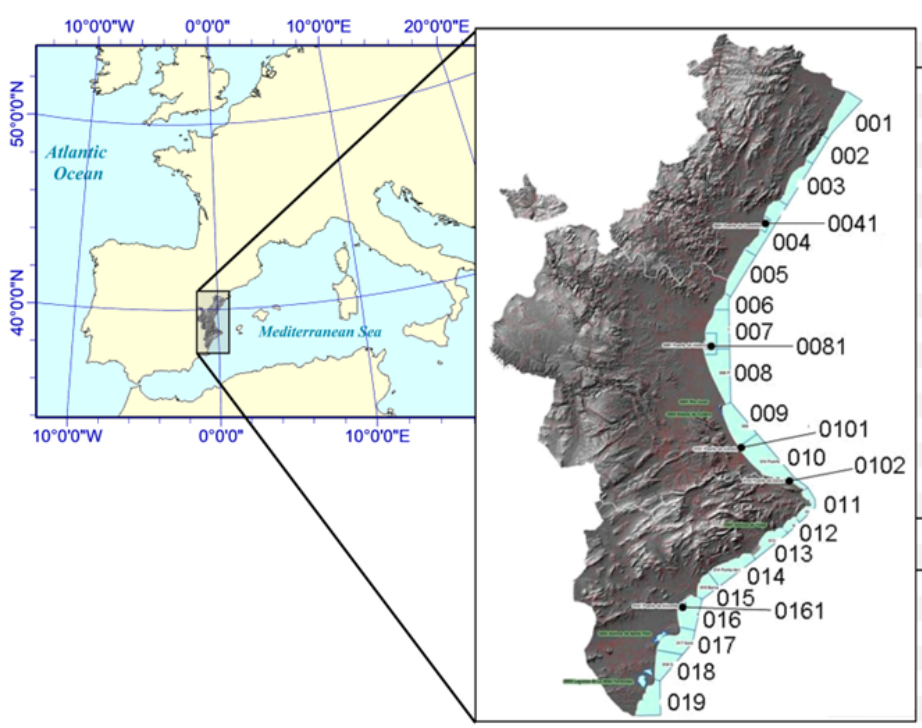

\begin{tabular}{c|l}
\multicolumn{1}{|c}{ COASTAL ZONES } \\
CODE & DENOMINATION \\
\hline $\mathbf{0 0 1}$ & Comunitad Valenciana boundary- Irta mountain range \\
$\mathbf{0 0 2}$ & Irta mountain range \\
$\mathbf{0 0 3}$ & Irta mountain range-Cape Oropesa \\
$\mathbf{0 0 4}$ & Cape Oropesa-Burriana \\
$\mathbf{0 0 5}$ & Burriana-Canet d'en Berenguer \\
$\mathbf{0 0 7}$ & North coast of Valencia \\
$\mathbf{0 0 8}$ & Port of Valencia-Cape Cullera \\
$\mathbf{0 0 9}$ & Cape Cullera-Port of Gandia \\
$\mathbf{0 1 0}$ & Port of Gandia-Cape San Antonio \\
$\mathbf{0 1 1}$ & Cape San Antonio- Cape Moraira \\
$\mathbf{0 1 2}$ & Cape Moraira-Rock of Ifach \\
$\mathbf{0 1 3}$ & Rock of Ifach-Cape Les Caletes \\
$\mathbf{0 1 4}$ & Cape Les Caletes-Cliff Aguas de Busot \\
$\mathbf{0 1 5}$ & Cliff Aguas de Busot-Cape Huertas \\
$\mathbf{0 1 6}$ & Cape Huertas- Santa Pola \\
$\mathbf{0 1 7}$ & Santa Pola Guardamar del Segura \\
$\mathbf{0 1 8}$ & Guardamar del Segura-Cape Cervera \\
$\mathbf{0 1 9}$ & Cape Cervera-Comunidad Valenciana boundary \\
\hline & \multicolumn{1}{|c}{ PORT ZONES } \\
CODE & DENOMINATION \\
\hline $\mathbf{0 0 4 1}$ & Port of Castellón \\
$\mathbf{0 0 6}$ & Port of Sagunto \\
$\mathbf{0 0 8 1}$ & Port of Valencia \\
$\mathbf{0 1 0 1}$ & Port of Gandia \\
$\mathbf{0 1 0 2}$ & Port of Denia \\
$\mathbf{0 1 6 1}$ & Port of Alicante \\
&
\end{tabular}

Fig. 1 Study area (Valencia Community, Spain)

\section{Sample collection}


In each zone 4 simple samples were taken to mix into a composite sample per zone from 2010 to 2015 yielding a total of 96 integrated samples.

The upper layer of collected sediment was approximately 6 to $10 \mathrm{~cm}$ thick. Sampling was carried out by trained personnel by means of $20 \mathrm{~mL}$ methacrylate corers. The corers were then placed in portable refrigerator, taken to the laboratory as quickly as possible and stored at $-20^{\circ} \mathrm{C}$ until analysed.

\section{Analytical techniques}

The sediments were freeze dried (ilShin FD5510 freeze dryer) and dry sieved. The heavy metals were determined using acid digestion with nitric acid (65\% Merck, Suprapur) and hydrogen peroxide (30\% Merck, Suprapur) in a Milestone Ethos 1 microwave according to the EPA 3051 method to obtain the solution of the total metal content.

Analyses of cadmium $(\mathrm{Cd})$, copper $(\mathrm{Cu})$, lead $(\mathrm{Pb})$, chromium $(\mathrm{Cr})$, nickel $(\mathrm{Ni})$, zinc $(\mathrm{Zn})$ and metalloid arsenic (As) were performed by Graphite Furnace Atomic Absorption Spectrometry or Flame Atomic Absorption Spectrometry (AAnalyst 800 Perkin Elmer with Zeeman correction), according to the metal concentration. Mercury (Hg) was determined by the cold vapour technique on an Atomic Absorption Spectrometer with autosampler (AS 90) and a flow injection system (FIAS 100). All the processes were performed in accordance with the APHA (2012).

Data were analysed as total metal concentrations on a dry weight basis and are expressed in acid soluble $m g \mathrm{~kg}^{-1}$ dry weight ( $\mathrm{mg} \mathrm{kg}^{-1} \mathrm{dw}$ ). The detection limits (LOD) and quantification limits (LOQ) expressed in acid soluble $\mu \mathrm{g} \mathrm{kg}^{-1} \mathrm{dw}$ were: LOD, Cr 5.57; Cd 1.23; Ni 10.55; Pb 11.61; Hg 13.21; Cu 15.92; As 14.94 and $\mathrm{Zn}$ expressed in $\mathrm{mg} \mathrm{kg}^{-1} \mathrm{dw}$ 1.02. The LOQ determined were $\mathrm{Cr} 18.56$; $\mathrm{Cd}$ 4.08; Ni 35.16; $\mathrm{Pb}$ 38.70; $\mathrm{Hg}$ 44.02; $\mathrm{Cu}$ 53.07; As 49.79 and $\mathrm{Zn}$ expressed in $\mathrm{mg} \mathrm{kg}^{-1} \mathrm{dw} 3.41$.

The routine procedure involves duplicate digestion and metal measurement to test analytical reproducibility. To prevent contamination, all glassware, plasticware and equipment used were washed prior to use by soaking in $20 \% \mathrm{HNO}_{3}$ for $24 \mathrm{~h}$ and rinsed with Milli-Q water. To identify background contamination, procedural blanks were analysed for every ten samples.

\section{Statistical analysis}

The data were subjected to a multivariate statistical cluster analysis. Statistical analyses were applied to experimental data transformed by $\operatorname{Ln}(\mathrm{x})$ to achieve normally distributed data. A cluster analysis (CA) was performed on the transformed data set using Ward's method with squared Euclidean distances as a 
measure of similarity. This technique was used to find any similarities between the sampling zones and identify relatively homogeneous groups of samples with similar properties.

A Pearson correlation test was applied to examine the relationship between the measured variables (i.e. the different heavy metals measured). The statistical analyses were conducted on SPSS 16.0.

\section{Assessing sediment contamination}

Numerical sediment quality assessment guidelines may be used to identify and designate sediments with high, moderate, and low probabilities of being associated with adverse effects on aquatic organisms. Of the numerous Sediment Quality Guidelines (SQGs) available, two (Long et al. 1995 and Macdonald et al. 1996) were used in this study in addition to five others to assess the degree of heavy metal contamination and ecological risks.

\section{a) Sediment Quality Guidelines (SQGs)}

The sediment quality assessment guidelines provide two guideline values for several contaminant substances (trace metals, total polychlorinated biphenyls PCBs, pesticides, polynuclear aromatic hydrocarbons PAHs). These two values define concentration ranges that are rarely, occasionally, or frequently associated with adverse effects. Sediment Quality Guideline values (Table 1) were established by Long et al. (1995) to estimate the biological effects of sediments for the protection of organism living in or near sediments (Zhao et al. 2014; Pejman et al. 2015). This SQG involves ELR (effects of low range) and ERM (effects of median range) values. Other SQGs values (Table 1) set by Macdonald et al. (1996) contain the TEL (threshold effect level) and PEL (probable effect level) values. ERL and TEL (low range values) are concentrations below which adverse effects are not expected, while ERM and PEL are concentrations above which adverse effects can be expected more often than not.

Table 1 Sediment Quality Guideline values (mg kg-1, dry weight). (ERL) Effects of Low Range and (ERM) Effects of Median Range; (TEL) Threshold Effect Level and (PEL) Probable Effect Level [*] Long et al. (1995); [**] Macdonald et al. (1996)

\begin{tabular}{l|lllllllll}
\hline & Cr & Cd & Ni & Pb & Hg & Cu & Zn & As & \\
\hline ERL & 8.1 & 1.2 & 20.9 & 46.7 & 0.150 & 34.0 & 150.0 & 8.2 & \\
ERM & 370.0 & 9.6 & 51.6 & 218.0 & 0.710 & 270.0 & 410.0 & 70.0 & {$\left[{ }^{*}\right]$} \\
\hline TEL & 52.3 & 0.68 & 15.9 & 30.2 & 0.13 & 18.7 & 124.0 & 7.24 & $\left.{ }^{* *}\right]$ \\
PEL & 160.0 & 4.21 & 42.8 & 112.0 & 0.70 & 108.0 & 271.0 & 41.6 & \\
\hline
\end{tabular}


b) Pollution Index

The sediment pollution indices applied in this work were the Ecological Risk Indices (Mean Effects Range Median quotient (MERMQ), mean PEL quotients (m-PEL-Q)) and Background Enrichment Indices (Potential Ecological Risk Index (RI), Pollution Load Index (PLI), modified Degree of Contamination (mCd) (Christophoridis et al. 2009; Gao et al. 2012; Li et al. 2013; Zhao et al. 2014; Pejman et al. 2015).

- $\quad$ Mean Effects Range Median quotient (MERMQ)

The MERMQ was calculated (Eq. 1) by dividing each chemical concentration by its respective ERM and averaging the individual quotients (Long et al. 2000).

$M E R M Q=\frac{\sum_{i=1}^{n} C_{i} / E R M_{i}}{n}$

Where $C_{i}$ is the concentration of metal $i$ in analysed sediments, $E R M_{i}$ (Effects Range Median) is the guideline values reported by Long et al. (1995) (Table 1) for the metal $i$ and $n$ is the number of metals. In this index all the contaminants were combined in a single value for four risk levels of the MERMQ index: MERMQ $\leq 0.1$ (low priority risk level and 9\% probability of being toxic); $0.1<$ MERMQ $\leq 0.5$ (medium-low priority risk level and $21 \%$ probability of being toxic); $0.5<\mathrm{MERMQ} \leq 1.5$ (high-medium priority risk level and $49 \%$ probability of being toxic); MERMQ $>0.5$ (high priority risk level and $76 \%$ probability of being toxic).

- $\quad$ mean PEL quotients (m-PEL-Q)

This index combines metal content and PEL-SQG values for the measured heavy metals (As, Cr, Ni Cd, $\mathrm{Cu}, \mathrm{Zn}, \mathrm{Hg}$ and $\mathrm{Pb}$ ). The m-PEL-Q index was calculated by Eq.(2) (Long et al. 1998):

$m-P E L-Q=\frac{\sum_{i=1}^{n}\left(C_{i} / P E L_{i}\right)}{n}$

Where $C_{i}$ is the measured metal concentration $(i), P E L_{i}$ is the PEL value of metal $(i)$, and $n$ is the number of metals. Several toxicity probability classes were defined for biota: $\mathrm{mPEL}$ quotients $\leq 0.1$ with $8 \%$ probability of being toxic, $0.11-1.5$ with $21 \%$ probability of being toxic, $1.51-2.3$ with $49 \%$ probability of being toxic, and $\geq 2.3$ with $73 \%$ probability of being toxic.

- $\quad$ Potential Ecological Risk Index (RI) 
The potential ecological risk index (RI) (Hakanson 1980) was used to analyse the ecological risk of heavy metals in the study zone (Pejman et al. 2015) by Eqs.(3) and (4):

$R I=\sum_{i=1}^{n} E_{r}^{i}=\sum_{i=1}^{n} T_{r}^{i} \times C_{f}^{i}$

$C_{f}^{i}=\frac{C_{s}^{i}}{C_{n}^{i}}$

where $E_{r}^{i}$ is the potential ecological risk factor of each heavy metal, $T_{r}^{i}$ is the toxic response factor of heavy metal $i$ (e.g., $\mathrm{Cd}=30, \mathrm{Hg}=40, \mathrm{Cu}=\mathrm{Pb}=\mathrm{Ni}=5, \mathrm{Cr}=2, \mathrm{Zn}=1, \mathrm{As}=10), C_{f}^{i}$ is the contamination factor of heavy metal $i, C_{s}^{i}$ is the concentration of heavy metal $i$ in the sediment, $C_{n}^{i}$ is the background value of heavy metal $i$. Following Hakanson (1980), the following tiers were used for the RI value: i) $\mathrm{RI}<150$ (low ecological risk); ii) $150 \leq \mathrm{RI} \geq 300$ (moderate ecological risk); iii) $300 \leq \mathrm{RI} \geq 600$ (considerable ecological risk); iv) RI>600 (very high ecological risk).

- Pollution Load Index (PLI)

This index was used to assess the degree of anthropogenic metal contamination as calculated by Eqs.(5), (6):

$P L I=\sqrt[n]{C_{f}^{1} \times C_{f}^{2} \times C_{f}^{3} \times \ldots \times C_{f}^{n}}$

$C_{f}^{i}=\frac{C_{s}^{i}}{C_{n}^{i}}$

where $C_{s}^{i}$ and $C_{n}^{i}$ are concentration of metal and background content, respectively, of metal $i$.

PLI $>1$ signifies contamination and $\mathrm{PLI}<1$ absence of pollution.

- Degree of Contamination

Introduced by Hakanson (1980), this index was originally a method of calculating an overall pollution factor based on seven metals and one organic contaminant (PCB). Individual Contamination Factors were based on the following formula, Eq.(7):

$C_{f}^{i}=\frac{C_{s}^{i}}{C_{n}^{i}}$

where $\mathrm{C}_{\mathrm{s}}^{\mathrm{i}}$ is the concentration of metal in at least five sub-samples and $\mathrm{C}_{\mathrm{n}}^{\mathrm{i}}$ is the concentration of metal in the selected reference background. The overall degree of contamination is given by Eq.(8): 
$\mathrm{C}_{\mathrm{d}}=\sum_{\mathrm{i}=1}^{8} \mathrm{C}_{\mathrm{f}}^{\mathrm{i}}$

Since it is not always feasible to analyse all the components in this index, a generalized index was proposed in Abrahim and Parker (2008) to provide the modified degree of contamination as calculated by Eq.(9):

$m C_{d}=\frac{\sum_{i=1}^{i=n} C_{f}^{i}}{n}$

where $C_{f}^{i}$ is contamination factor, $n=$ number of analysed elements and $i=\mathrm{i}^{\text {th }}$ element. According to the modified degree of contamination values, each sample falls into one of the seven tiers: i) $\mathrm{mCd}<1.5$ (nil to very low degree of contamination); ii) $1.5 \leq \mathrm{mCd}<2$ (low degree of contamination); iii) $2 \leq \mathrm{mCd}<4$ (moderate); iv) $4 \leq \mathrm{mCd}<8$ (high); v) $8 \leq \mathrm{mCd}<16$ (very high); vi) $16 \leq \mathrm{mCd}<32$ (extremely high); vii) $\mathrm{mCd} \geq 32$ (ultra-high degree of contamination).

\section{Results}

\section{Heavy metal content in surface sediment}

The heavy metal contents analysed in the sediments from the Valencia coastline are summarized in Table 2. The average concentration range in all the study zones were: $4.64-28.97 \mathrm{mg} \mathrm{kg}^{-1}$ for $\mathrm{Cr}, 0.11-0.29 \mathrm{mg}$ $\mathrm{kg}^{-1}$ for $\mathrm{Cd}$, 1.92-17.01 $\mathrm{mg} \mathrm{kg}^{-1}$ for $\mathrm{Ni}, 8.72-57.13 \mathrm{mg} \mathrm{kg}^{-1}$ for $\mathrm{Zn}, 2.19-9.33 \mathrm{mg} \mathrm{kg}^{-1}$ for Pb, 0.01-0.18 $\mathrm{mg}$ $\mathrm{kg}^{-1}$ for $\mathrm{Hg}$, 1.18-6.53 $\mathrm{mg} \mathrm{kg}^{-1}$ for $\mathrm{Cu}$ and 2.71-36.21 $\mathrm{mg} \mathrm{kg}^{-1}$ for As. The order of the average sediment metal content (highest to lowest) is as follows: $\mathrm{Zn}>\mathrm{As}>\mathrm{Cr}>\mathrm{Ni}>\mathrm{Pb}>\mathrm{Cu}>\mathrm{Cd}>\mathrm{Hg}$.

There was a large spatial and temporal dispersion in the metal concentration data. In the norther coast concentration values were higher than in the south. For example, zones 001 to 003 exhibited greater $\mathrm{Ni}$ and As values of up to $80-86 \%$ larger than in the southern areas such as 013 to 016 . For other metals this variation is up to $75 \%$ for $\mathrm{Zn}$ and $\mathrm{Cr}, 60 \%$ for $\mathrm{Cu}$, and $40 \%$ for $\mathrm{Pb}$ and $\mathrm{Cd}$.

In the remaining southern zones (017 to 019), almost all the metals registered higher concentrations, although these were still lower than those obtained in the northern areas (001 to 003).

Zones 016 and 017 exhibit larger $\mathrm{Hg}$ concentration with values of 0.145 and $0.182 \mathrm{mg} \mathrm{kg}^{-1} \mathrm{dw}$, respectively. Spatial differences for this metal were also established between northern areas 001 to 010 , with values $77 \%$ higher than southern areas, 011 to 015 . As with the other metals, the $\mathrm{Hg}$ values were highest in the two southernmost zones 018 and 019. 
The values obtained for port areas reveal a spatial distribution similar to the coastal zones. The northernmost port areas (Castellón, Sagunto, Valencia and Gandia) exhibit higher concentrations than the ports of Denia and Alicante in the south, although the concentrations in these port areas in no case exceeded the values of northern coast zones 001 to 003 .

The temporal dispersion of the concentrations throughout the 4-year study period showed high Variation Coefficients (data not shown) around 30-50\%, in most areas. Some zones $(015,018,019,0041$ and 0081$)$ had $\mathrm{Hg}$ standard deviation values equal to or greater than the average value because the value in one of the 4 years studied was noticeably higher than the other three (e.g. in zone $019,0.022,0.074,0.005$ and $0.007 \mathrm{mg} \mathrm{kg}^{-1}$ for 2010, 2011, 2012 and 2015, respectively). 
Table 2 Summary of heavy metal concentration in surface sediment at the study zone (2010, 2011, 2012 and 2015 years).

The concentrations are given as Mean \pm Standard Deviation (SD).

\begin{tabular}{|c|c|c|c|c|c|c|c|c|c|}
\hline \multicolumn{2}{|c|}{ Zones } & $\underset{\left(\mathrm{mg} \mathrm{kg}^{-1} \mathrm{dw}\right)}{\mathrm{Cr}}$ & $\begin{array}{c}\text { Cd } \\
\left(\mathrm{mg} \mathrm{kg}^{-1} \mathrm{dw}\right)\end{array}$ & $\underset{\left(\mathrm{mg} \mathrm{kg}^{-1} \mathrm{dw}\right)}{\mathrm{Ni}}$ & $\begin{array}{c}P b \\
\left(\mathrm{mg} \mathrm{kg}^{-1} \mathrm{dw}\right)\end{array}$ & $\underset{\left(\mathrm{mg} \mathrm{kg}^{-1} \mathrm{dw}\right)}{\mathrm{Hg}}$ & $\underset{\left(\mathrm{mg} \mathrm{kg}^{-1} \mathrm{dw}\right)}{\mathrm{Cu}}$ & $\underset{\left(\mathrm{mg} \mathrm{kg}^{-1} \mathrm{dw}\right)}{\mathrm{Zn}}$ & $\begin{array}{c}\text { As } \\
\left(\mathrm{mg} \mathrm{kg}^{-1} \mathrm{dw}\right)\end{array}$ \\
\hline \multirow{14}{*}{ 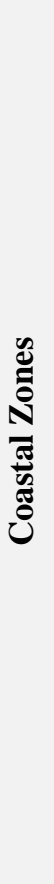 } & 001 & $28.93 \pm 8.91$ & $0.239 \pm 0.049$ & $15.80 \pm 1.84$ & $8.83 \pm 3.76$ & $0.043 \pm 0.010$ & $5.32 \pm 1.09$ & $56.47 \pm 4.81$ & $27.55 \pm 7.32$ \\
\hline & 002 & $26.46 \pm 7.62$ & $0.248 \pm 0.032$ & $14.48 \pm 1.27$ & $6.13 \pm 2.43$ & $0.026 \pm 0.014$ & $4.66 \pm 1.07$ & $52.05 \pm 5.78$ & $26.27 \pm 7.07$ \\
\hline & 003 & $28.97 \pm 7.87$ & $0.293 \pm 0.045$ & $17.01 \pm 1.20$ & $5.73 \pm 2.83$ & $0.032 \pm 0.017$ & $4.58 \pm 0.98$ & $57.13 \pm 7.38$ & $36.21 \pm 12.26$ \\
\hline & 004 & $20.09 \pm 7.33$ & $0.190 \pm 0.016$ & $10.60 \pm 2.59$ & $4.98 \pm 1.33$ & $0.025 \pm 0.013$ & $2.78 \pm 0.93$ & $35.71 \pm 0.32$ & $23.35 \pm 10.26$ \\
\hline & 005 & $13.34 \pm 4.33$ & $0.164 \pm 0.037$ & $6.46 \pm 0.83$ & $3.83 \pm 1.10$ & $0.027 \pm 0.007$ & $1.96 \pm 0.38$ & $32.71 \pm 5.04$ & $13.49 \pm 4.24$ \\
\hline & 008 & $25.79 \pm 10.11$ & $0.287 \pm 0.056$ & $13.38 \pm 1.87$ & $8.02 \pm 2.72$ & $0.042 \pm 0.023$ & $3.81 \pm 0.78$ & $48.71 \pm 9.86$ & $29.68 \pm 12.04$ \\
\hline & 009 & $24.70 \pm 9.49$ & $0.278 \pm 0.059$ & $12.53 \pm 2.25$ & $7.26 \pm 3.24$ & $0.060 \pm 0.025$ & $3.53 \pm 0.92$ & $42.23 \pm 7.90$ & $27.20 \pm 8.04$ \\
\hline & 010 & $16.88 \pm 4.28$ & $0.232 \pm 0.024$ & $8.37 \pm 1.53$ & $5.57 \pm 2.67$ & $0.034 \pm 0.018$ & $3.88 \pm 1.96$ & $32.85 \pm 11.14$ & $19.08 \pm 7.05$ \\
\hline & 011 & $11.82 \pm 4.05$ & $0.246 \pm 0.028$ & $4.44 \pm 1.22$ & $4.78 \pm 1.76$ & $0.014 \pm 0.003$ & $2.44 \pm 0.38$ & $18.99 \pm 5.15$ & $18.83 \pm 5.55$ \\
\hline & 012 & $11.97 \pm 6.80$ & $0.183 \pm 0.019$ & $2.74 \pm 0.44$ & $5.75 \pm 2.50$ & $0.009 \pm 0.002$ & $1.45 \pm 0.22$ & $13.35 \pm 2.89$ & $9.48 \pm 5.37$ \\
\hline & 016 & $5.23 \pm 1.83$ & $0.120 \pm 0.006$ & $2.00 \pm 0.51$ & $6.48 \pm 2.49$ & $0.145 \pm 0.040$ & $1.73 \pm 0.22$ & $13.77 \pm 3.04$ & $3.44 \pm 0.96$ \\
\hline & 017 & $10.76 \pm 2.81$ & $0.165 \pm 0.028$ & $4.87 \pm 0.75$ & $9.33 \pm 3.27$ & $0.182 \pm 0.060$ & $5.01 \pm 1.3$ & $31.67 \pm 10.87$ & $5.07 \pm 1.71$ \\
\hline & 018 & $16.39 \pm 4.37$ & $0.149 \pm 0.016$ & $10.12 \pm 2.55$ & $4.04 \pm 1.95$ & $0.041 \pm 0.039$ & $6.53 \pm 1.62$ & $29.05 \pm 6.01$ & $6.32 \pm 2.91$ \\
\hline & 019 & $8.10 \pm 2.83$ & $0.126 \pm 0.012$ & $4.52 \pm 0.85$ & $3.76 \pm 1.60$ & $0.038 \pm 0.046$ & $1.69 \pm 0.22$ & $18.98 \pm 6.20$ & $10.95 \pm 5.36$ \\
\hline \multirow{6}{*}{ 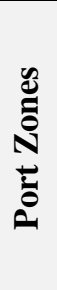 } & 0041 & $16.70 \pm 5.72$ & $0.205 \pm 0.020$ & $9.20 \pm 1.10$ & $5.28 \pm 2.85$ & $0.060 \pm 0.075$ & $3.20 \pm 0.3$ & $37.66 \pm 6.50$ & $19.07 \pm 6.43$ \\
\hline & 006 & $15.70 \pm 5.77$ & $0.128 \pm 0.009$ & $10.32 \pm 7.52$ & $5.10 \pm 2.06$ & $0.158 \pm 0.128$ & $5.08 \pm 4.6$ & $37.98 \pm 21.28$ & $18.05 \pm 5.37$ \\
\hline & 0081 & $13.98 \pm 2.37$ & $0.140 \pm 0.036$ & $6.82 \pm 1.18$ & $7.24 \pm 1.41$ & $0.047 \pm 0.059$ & $3.46 \pm 0.96$ & $30.83 \pm 11.14$ & $19.98 \pm 5.73$ \\
\hline & 0101 & $17.31 \pm 7.15$ & $0.202 \pm 0.009$ & $9.07 \pm 2.57$ & $7.05 \pm 2.70$ & $0.038 \pm 0.027$ & $4.63 \pm 1.59$ & $36.01 \pm 4.97$ & $17.72 \pm 5.42$ \\
\hline & 0102 & $9.30 \pm 3.44$ & $0.113 \pm 0.029$ & $3.90 \pm 0.67$ & $6.11 \pm 1.51$ & $0.027 \pm 0.020$ & $1.84 \pm 0.56$ & $21.86 \pm 5.23$ & $27.21 \pm 16.22$ \\
\hline & 0161 & $7.90 \pm 3.50$ & $0.176 \pm 0.016$ & $3.43 \pm 1.33$ & $8.71 \pm 3.75$ & $0.076 \pm 0.032$ & $3.79 \pm 1.32$ & $21.86 \pm 1.58$ & $4.01 \pm 1.35$ \\
\hline
\end{tabular}




\section{Multivariate statistical analyses}

A cluster analysis was carried out to study the spatial variation of the heavy metal concentrations in depth. Figure 2 shows the dendogram of the cluster analysis obtained.

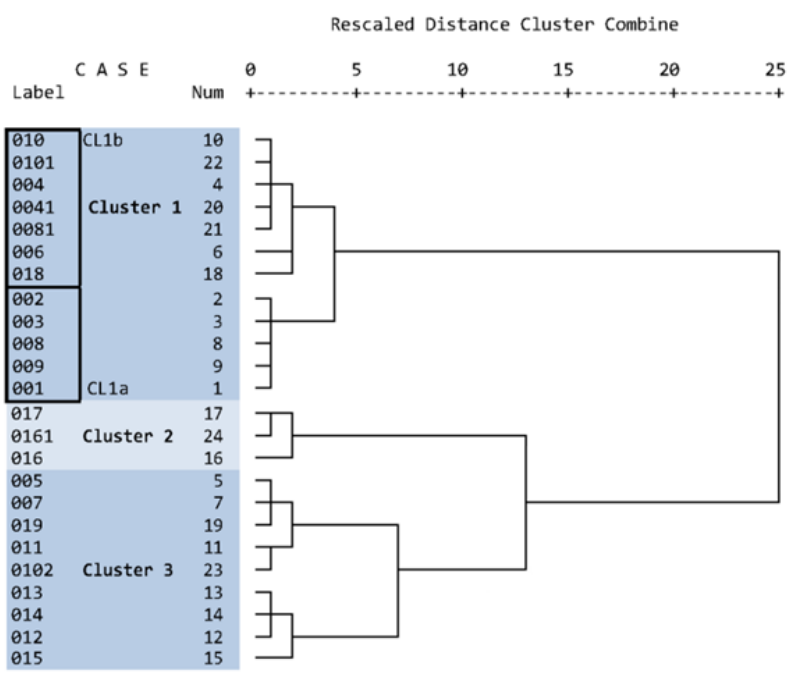

Fig. 2 Dendogram of cluster analysis for all zones of the study area

Three main different clusters, each with different subgroups, can be seen. The first cluster (CL1) contains the sites with the highest heavy metal concentration. This cluster may be divided into two subgroups (CL1a and CL1b). Subgroup CL1a contains the northern areas (001,002 and 003) and some central areas, such as 008 and 009. The second subgroup, CL1b, contains mainly harbour areas $(0041,006,0081$, 0101). Zone 018 had high metal concentrations and is also part of this cluster (CL1b), despite being in the south.

The second (CL2) and third cluster (CL3) contain the moderate and low concentration sites, respectively. CL2 is formed by coastal zones 016,017 and the port area 0161 . CL3 contains zones $005,007,011$ to 015, 019 and the port area 0102 . These sites are mostly in the south of the study area.

The Pearson correlation coefficient was calculated to determine the correlation between the heavy metal concentrations. The correlation matrix for the variables measured is shown in Table 3. 
Table 3 Correlations coefficients of heavy metals in surface sediments

\begin{tabular}{|c|c|c|c|c|c|c|c|c|c|}
\hline & & $\mathrm{Cr}$ & Cd & $\mathbf{N i}$ & $\mathbf{P b}$ & Hg & $\mathrm{Cu}$ & Zn & As \\
\hline $\mathrm{Cr}$ & $\begin{array}{l}\text { Correlation } \\
\text { Sig.(bilateral) }\end{array}$ & 1.000 & & & & & & & \\
\hline Cd & $\begin{array}{l}\text { Correlation } \\
\text { Sig.(bilateral) }\end{array}$ & $\begin{array}{l}0.713^{* *} \\
0.000\end{array}$ & 1.000 & & & & & & \\
\hline \multirow[t]{2}{*}{$\mathbf{N i}$} & Correlation & $0.955^{* *}$ & $0.610 * *$ & 1.000 & & & & & \\
\hline & Sig.(bilateral) & 0.000 & 0.002 & & & & & & \\
\hline \multirow[t]{2}{*}{$\mathbf{P b}$} & Correlation & $0.475^{*}$ & 0.383 & 0.374 & 1.000 & & & & \\
\hline & Sig.(bilateral) & 0.019 & 0.064 & 0.072 & & & & & \\
\hline \multirow[t]{2}{*}{ Hg } & Correlation & 0.147 & -0.113 & 0.229 & $0.582 * *$ & 1.000 & & & \\
\hline & Sig.(bilateral) & 0.494 & 0.598 & 0.281 & 0.003 & & & & \\
\hline \multirow[t]{2}{*}{ Cu } & Correlation & $0.701 * *$ & $0.459 *$ & $0.765 * *$ & $0.581 * *$ & $0.493^{*}$ & 1.000 & & \\
\hline & Sig.(bilateral) & 0.000 & 0.024 & 0.000 & 0.003 & 0.014 & & & \\
\hline \multirow[t]{2}{*}{ Zn } & Correlation & $0.922 * *$ & $0.576 * *$ & $0.953 * *$ & $0.568 * *$ & $0.408^{*}$ & $0.789 * *$ & 1.000 & \\
\hline & Sig.(bilateral) & 0.000 & 0.003 & 0.000 & 0.004 & 0.048 & 0.000 & & \\
\hline \multirow[t]{2}{*}{ As } & Correlation & $0.841 * *$ & $0.525 * *$ & $0.793 * *$ & 0.375 & 0.033 & 0.385 & $0.780 * *$ & 1.000 \\
\hline & Sig.(bilateral) & 0.000 & 0.008 & 0.000 & 0.071 & 0.878 & 0.063 & 0.000 & \\
\hline
\end{tabular}

High positive correlations $(\mathrm{p}<001)$ were found for $\mathrm{Cr}-\mathrm{Ni}, \mathrm{Cr}-\mathrm{Zn}$ and Ni-Zn with a Pearson Coefficient higher than 0.922 . Moderately positive correlations $(\mathrm{p}<001)$ were obtained for $\mathrm{As}, \mathrm{Cu}$ and $\mathrm{Cd}$ with the first three metals ((As-Cr(0.841), As-Ni(0.793); As-Zn (0.780) and $\mathrm{Cu}-\mathrm{Ni}(0.765), \mathrm{Cu}-\mathrm{Zn}(0.789)$ and $\mathrm{Cu}-$ $\mathrm{Cr}(0.701), \mathrm{Cd}-\mathrm{Cr}(0.713)$ and $\mathrm{Cd}-\mathrm{Ni}(0.610))$.

A statistically significant correlation was also obtained $(\mathrm{p}<001)$ for $\mathrm{Pb}$ with the metals $\mathrm{Hg}, \mathrm{Cu}$ and $\mathrm{Zn}$, although in these cases the Pearson coefficients are lower $(\mathrm{Pb}-\mathrm{Hg}(0.582), \mathrm{Pb}-\mathrm{Cu}(0.581), \mathrm{Pb}-\mathrm{Zn}(0.568))$.

\section{Adverse effects associated with heavy metal pollution: Sediment Quality Guidelines and Pollution Indices}

The adverse effects of heavy metal levels on biological organisms in the sediments were evaluated by comparison with the available benchmark sediment quality guidelines and applying the different ecological pollution indices.

a) Comparison Sediment Quality Guidelines (SQGs) with sediment samples studied

Firstly, the values obtained for the Valencia coast (Table 2) are compared with SQG values proposed in Long et al. 1995 (Table 1). As can be seen in Figures 3a and 3b, the values for $\mathrm{Ni}, \mathrm{Pb}, \mathrm{Cu}, \mathrm{Zn}, \mathrm{Cd}$ and $\mathrm{Hg}$ are lower than the ERL values, so that no adverse effects can be expected on aquatic organisms due to the metal concentration found in the study. 
In zones 006 and 017 the $\mathrm{Hg}$ concentration is within the range defined by ERL-ERM (ERL $<[\mathrm{Hg}]<\mathrm{ERM})$, showing that the sediments in both zones can be associated with occasional adverse effects on benthic organisms (Fig. 3b).

Cr and As (Fig. 3c and Fig. 3d, respectively) in most areas show values within the ERL and ERM (ERL $<$ Cr, As] $<$ ERM) range. Only zones 014 to 016 and 0161 for $\mathrm{Cr}$ and zones 013 to 018 and 0161 for As have concentrations lower than the ERL.

Comparing the measured concentrations of metals with the SQGs values (TEL and PEL) proposed by Macdonald et al. 1996 (Table 1), $\mathrm{Cr}, \mathrm{Cd}, \mathrm{Pb}, \mathrm{Cu}$ and $\mathrm{Zn}$ metal concentrations are below the TEL (Fig. $4 a)$.

$\mathrm{Hg}$ and $\mathrm{Ni}$ exhibit for almost all zones, concentration values lower the TEL, excepted in zones 006, 016 and 017 for $\mathrm{Hg}$ (Fig. 4b) and zone 003 for Ni (Fig. 4d). In these areas values are within the range of TEL $<$ Hg, Ni $]<$ PEL. This also occurs for As (Fig. 4d), that shows 17 of 24 zones in the range defined by TEL and PEL values.

It should be noted that the concentration of all the metals studied in no case reached or exceeded the ERM and PEL. 

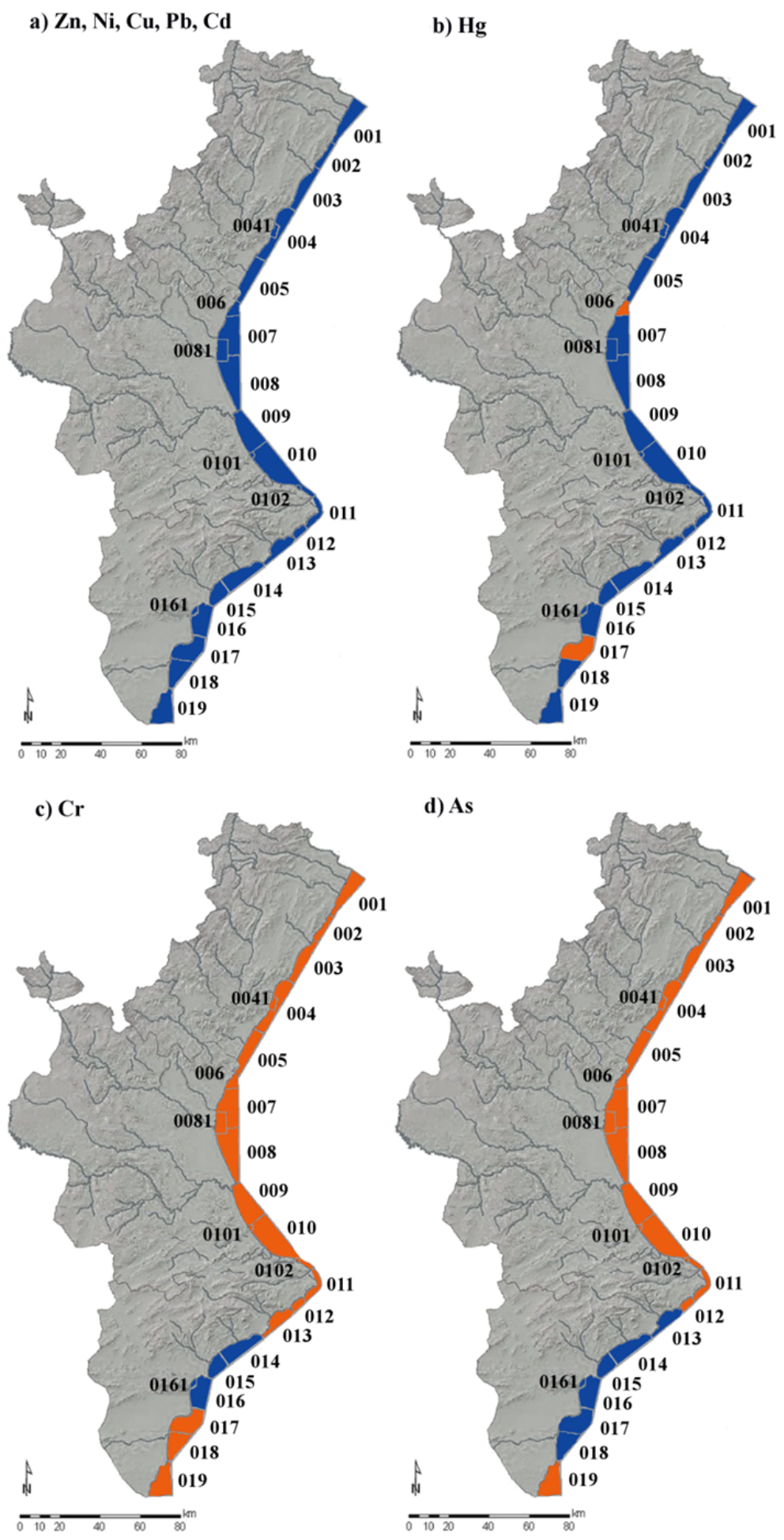

Fig. 3 Evaluation of the studied areas applying Sediment Quality Guidelines (SQGs) developed by Long et al. (1995). a) $\mathrm{Zn}, \mathrm{Ni}, \mathrm{Cu}, \mathrm{Pb}$ and $\mathrm{Cd}$; b) $\mathrm{Hg}$; c) Cr; d) $\mathrm{As}$

(Blue zones $=[$ metal $]<$ ERL; Orange zones $=$ ERL $<[$ metal $]<$ ERM) 

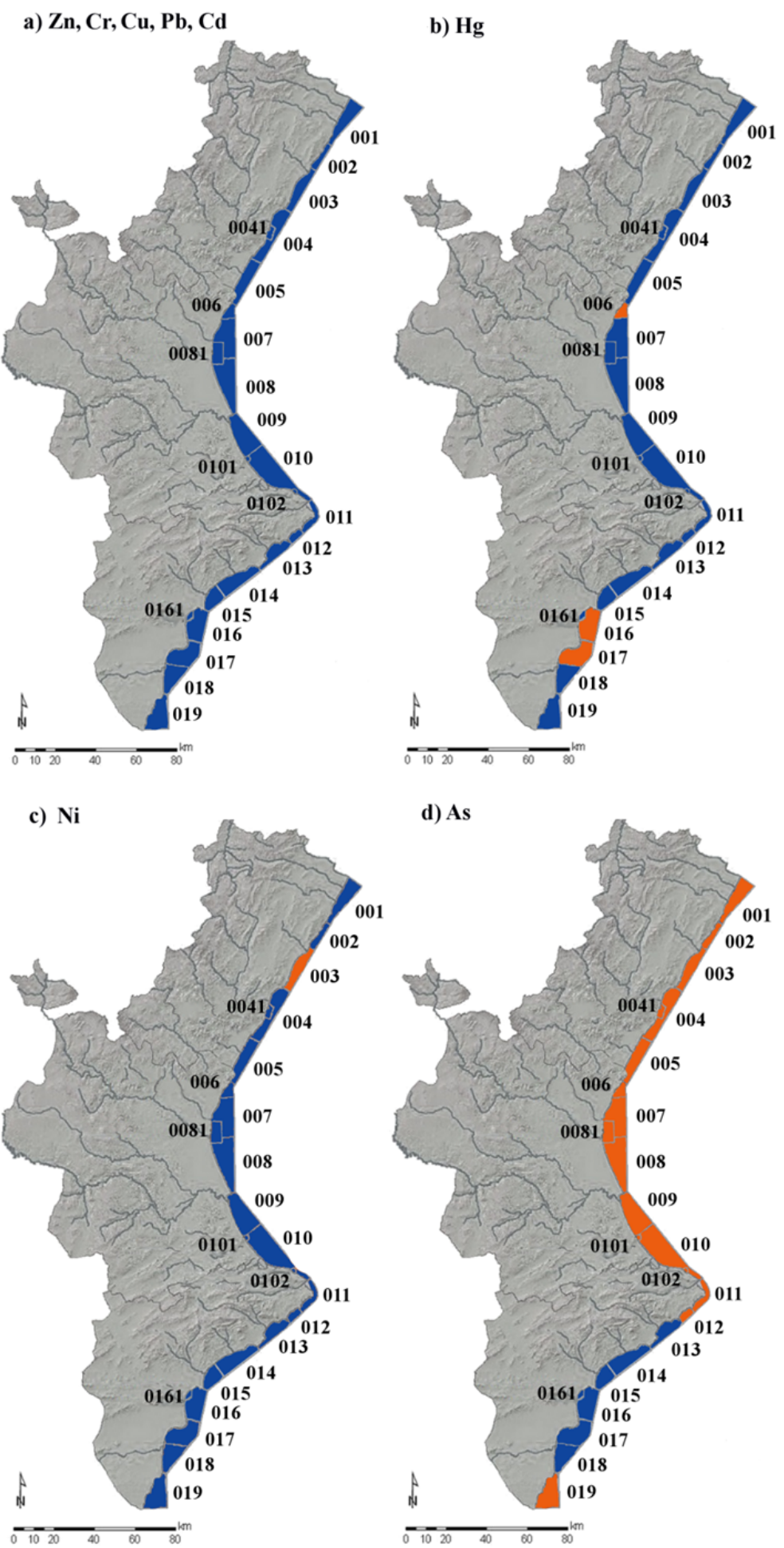

Fig. 4 Evaluation of the studied areas applying Sediment Quality Guidelines (SQGs) developed by Macdonald et al. (1996). a) $\mathrm{Zn}, \mathrm{Cr}, \mathrm{Cu}, \mathrm{Pb}$ and $\mathrm{Cd}$; b) $\mathrm{Hg}$; c) Ni; d) $\mathrm{As}$

(Blue zones $=[$ metal $]<$ TEL; Orange zones $=$ TEL $<[$ metal $]<$ PEL) 
b) Pollution Indices

Following the usual research practice (Gao et al. 2012; Pejman et al. 2015; Zhang et al. 2016) a series of indices based on the concentration of the measured metal were applied to determine any possible effects on aquatic organisms living in the sediments. The results can be seen in Fig. 5 and Table 4.

The background values of the study area must be known in order to apply these indexes. Most of the studies consulted use the average shale value as background values (Turekian and Weipohl 1961). However, as these values are much higher than the metal concentrations in the study area, statistical methods (Reimann et al. 2005) were used to determine the chemical backgrounds, consisting of the median value plus twice the absolute median deviation (Median+2DMA) of the values obtained for the sediments analysed. The calculated background values were: $\mathrm{Cr} 22.47 \mathrm{mg} \cdot \mathrm{kg}^{-1} ; \mathrm{Cd} 0.24 \mathrm{mg} \cdot \mathrm{kg}^{-1} ; \mathrm{Ni} 13.33$ $\mathrm{mg} \cdot \mathrm{kg}^{-1} ; \mathrm{Pb} 8.64 \mathrm{mg} \cdot \mathrm{kg}^{-1} ; \mathrm{Hg} 0.06 \mathrm{mg} \cdot \mathrm{kg}^{-1} ; \mathrm{Cu} 5.89 \mathrm{mg} \cdot \mathrm{kg}^{-1} ; \mathrm{Zn} 50.04 \mathrm{mg} \cdot \mathrm{kg}^{-1} ;$ As $35.61 \mathrm{mg} \cdot \mathrm{kg}^{-1}$. The zones were classified after applying the pollution indexes as follows:

\section{- $\quad$ Mean ERM quotient (MERMQ):}

According to the classification established for MERMQ, $75 \%$ of the zones have an index of $\leq 0.1$, which indicates a low priority risk level with toxicity probability of only $9 \%$. However, zones 001 to 003,006 , 008 and 009 were between 0.1 and $0.5(0.1<\mathrm{MERMQ} \leq 0.5)$, giving a medium-low priority risk level with a toxicity probability of $21 \%$.

- $\quad$ Mean PEL quotients (mPELq)

Ten of the 24 areas studied $(005,007,012$ to $016,018,019$ and 0161$)$ have a mPELq index of $<0.1$, giving a low toxicity probability of $8 \%$ for aquatic organisms, due to the levels of metals present in the sediment. The remaining 14 zones (001 to $004,006,008$ to $011,017,0041,0081,0101$ and 0102$)$ have a value for this index in the range of $0.11-1.5$, giving a toxicity probability of $49 \%$.

- Potential ecological Risk (RI):

All the zones have an index of $\mathrm{RI}<150$, which indicates that the set of metals measured in the sediments in the study area represent a low ecological risk. Within them the higher values of this index are presented in zones 016 and $006(122.4,142.4$, respectively). Only the zone 017 is classified as a moderate ecological risk since the RI values is $>150$ (159.6).

- Pollution Load Index (PLI): 
The values of the PLI index in all the zones scored a PLI value lower than 1, indicating the absence of contamination. However, it should be noted that zones 001 to 003,008 and 009 gave a PLI index close to $1(0.98,0.94,0.90$ and 0.88 , respectively).

- $\quad$ Modified Degree of Contamination $(\mathrm{mCd})$

The value obtained for the $\mathrm{mCd}$ index in the 24 zones was below 1.5, indicating little or no contamination. Once again, areas 001 to $003,006,008,009$ and 017 had the highest pollution index values. 
a) MERMQ
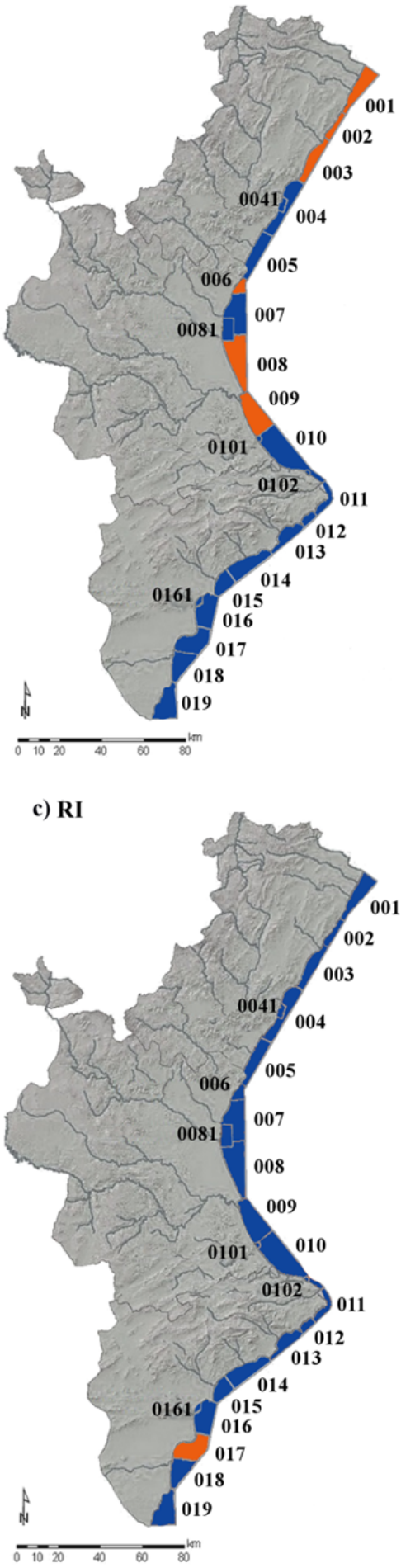

b) mPELq

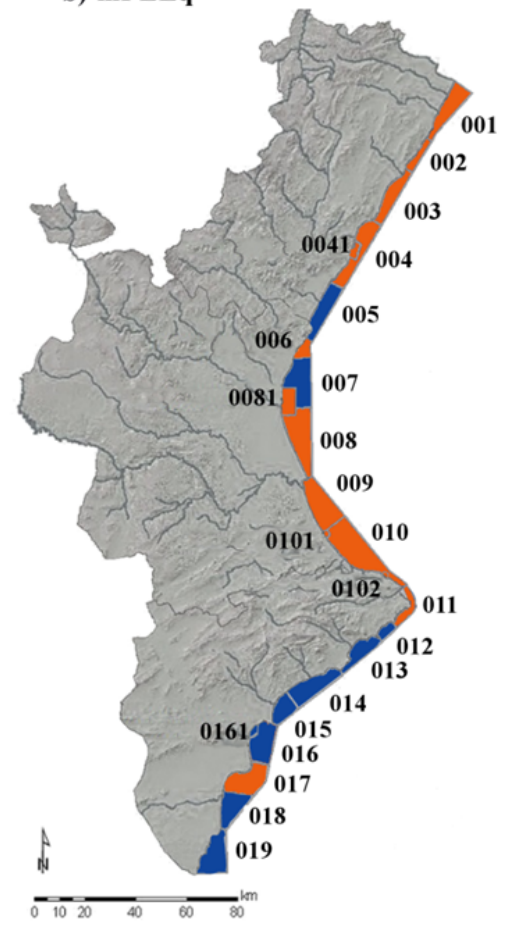

d) PLI, mCd

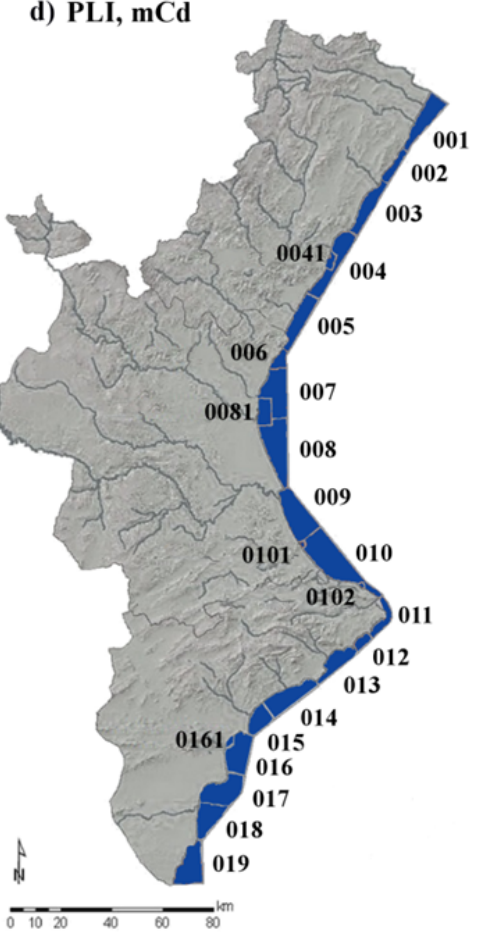

Fig. 5 Distribution of pollution index in the surface sediments of the Valencian coastline. a) MERQ index (blue zones $=$ MERQ inde $\leq 0.1$; orange zones $=0.1<$ MERQ $<0.5$ ); b) $\mathbf{m P E L q}$ index (blue zones $=\mathrm{mPELq}<0.1$; orange zones $=\mathrm{mPELq}$ between $0.11-1.5$ ); $\mathbf{c}$ ) $\mathbf{R I}$ index (blue zones $=\mathrm{RI}<150$; orange zones $=150<\mathrm{RI}<300$ ); d) PLI, mCd indices (blue zones $=\mathrm{PLI}<1$ and $\mathrm{mCd}<1.5$ ) 
Table 4 Pollution index values in Valencia coastal sediments

\begin{tabular}{|c|c|c|c|c|c|c|}
\hline \multicolumn{2}{|c|}{ ZONE } & MERMQ & mPELq & RI & PLI & $\overline{\text { mCd }}$ \\
\hline \multirow{18}{*}{ 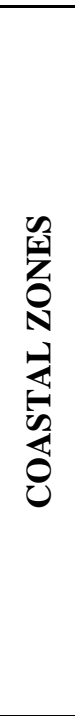 } & 001 & 0.13 & 0.21 & 85.1 & 0.97 & 0.99 \\
\hline & 002 & 0.12 & 0.19 & 71.5 & 0.83 & 0.87 \\
\hline & 003 & 0.15 & 0.23 & 85.1 & 0.94 & 0.98 \\
\hline & 004 & 0.10 & 0.15 & 58.3 & 0.64 & 0.66 \\
\hline & 005 & 0.06 & 0.10 & 50.5 & 0.48 & 0.50 \\
\hline & 007 & 0.06 & 0.09 & 46.7 & 0.43 & 0.44 \\
\hline & 008 & 0.13 & 0.20 & 88.1 & 0.90 & 0.92 \\
\hline & 009 & 0.12 & 0.19 & 97.7 & 0.88 & 0.90 \\
\hline & 010 & 0.08 & 0.13 & 68.3 & 0.66 & 0.67 \\
\hline & 011 & 0.06 & 0.11 & 53.2 & 0.46 & 0.49 \\
\hline & 012 & 0.04 & 0.07 & 37.9 & 0.33 & 0.38 \\
\hline & 013 & 0.04 & 0.06 & 34.5 & 0.32 & 0.36 \\
\hline & 014 & 0.03 & 0.05 & 31.3 & 0.27 & 0.30 \\
\hline & 015 & 0.02 & 0.03 & 31.2 & 0.20 & 0.23 \\
\hline & 016 & 0.05 & 0.07 & 122.4 & 0.35 & 0.59 \\
\hline & 017 & 0.08 & 0.11 & 159.6 & 0.64 & 0.91 \\
\hline & 018 & 0.06 & 0.10 & 61.1 & 0.57 & 0.63 \\
\hline & 019 & 0.05 & 0.08 & 51.1 & 0.39 & 0.41 \\
\hline \multirow{6}{*}{ 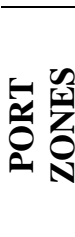 } & 0041 & 0.09 & 0.14 & 82.8 & 0.70 & 0.71 \\
\hline & 006 & 0.11 & 0.16 & 142.4 & 0.78 & 0.92 \\
\hline & 0081 & 0.08 & 0.13 & 67.0 & 0.63 & 0.63 \\
\hline & 0101 & 0.09 & 0.14 & 68.0 & 0.70 & 0.71 \\
\hline & 0102 & 0.08 & 0.13 & 46.7 & 0.45 & 0.47 \\
\hline & 0161 & 0.05 & 0.07 & 85.0 & 0.47 & 0.60 \\
\hline
\end{tabular}

\section{Discussion}

Most of Valencia's population and industries are concentrated along its coastline. The human activity in this narrow strip produces contaminants that have an impact on the different compartments (water, sediment, air) of the coastal system from urban and industrial discharges, fish farms, sea traffic in and out of large commercial ports, nautical sports, etc. In addition, the entire coastal area receives agricultural run-off containing a high proportion of micronutrients, pesticides, herbicides, etc.

Heavy metals are included in these pollutants that eventually reach the aquatic ecosystems. These elements due to their low solubility are quickly fixed on the solid material in suspension (Förstner and Wittmann 1981) that ultimately will be deposit on the sediments.

In some coastal zones studied $(003,006,010,011,014,016$ and 017$)$ the concentrations of the heavy metals found are in agreement with those reported in 1991 by Sanchiz et al. 2000.

These authors also detected high concentrations of $\mathrm{Hg}$ and $\mathrm{Pb}$ in the sediments in the south of Valencia Community, as in zone 017 , where the highest $\mathrm{Pb}$ and $\mathrm{Hg}$ values were obtained. 
Other studies carried out in the Mediterranean also reported noticeably higher metal concentrations than those obtained in the present study since their sampling station gather point sources of contamination such as the mouths of rivers (Palanques and Díaz 1990) or dredged sediment from ports areas (CasadoMartínez et al. 2009).

Our results reveal that the north of Valencia has higher concentrations of $\mathrm{Cr}, \mathrm{Ni}, \mathrm{Zn}$ and $\mathrm{Cd}$ than the other areas. These particular metals are characterized by their lithogenic origin, so that their presence in zones 001, 002 and 003 could be attributed to the nearby mountain ranges. It must be kept in mind that some heavy metals (unlike other priority substances or specific pollutants like pesticides, DDT, etc.), can have a natural origin and the existence of certain levels of heavy metals in an aquatic ecosystem does not necessarily imply anthropogenic pollution.

Other heavily concentrated sites are zones 008 and 009 , which receive pressures from densely populated areas with many industrial and agricultural activities.

Urban and industrial waste and wastewater management are the main sources in these areas of As, $\mathrm{Cr}, \mathrm{Ni}$, $\mathrm{Pb}$ and $\mathrm{Hg}$ (PRTR-España 2016). Furthermore, $\mathrm{Hg}$ is also released into the environment through the combustion of fossil fuels and from various industrial activities (Donze et al. 1990). In addition, Zn comes from the production and transformation of metals, the chemical industry and the food and beverage industry in the area. The coastline also receives the agricultural runoff with fertilizers that increase the $\mathrm{Cd}$ levels (Adriano 2001), as well as herbicides and pesticides that contain arsenic (Donze et al. 1990).

High metal contents were also found in areas 0041, 006, 0081 and 0101, which are near ports with intense maritime traffic. These zones are also influenced by the nearby industrial areas, so that the origin of these metals can be mostly considered as anthropic.

In areas near sea ports with commercial shipping activities and nautical sports activities, different hydrophobic complexes of $\mathrm{Cu}$ and $\mathrm{Zn}$ are commonly used in biocidal paints for boat maintenance (Turley et al. 2000; Parks et al. 2010). This indicated that residues of these compounds are detected with increasing frequency in coastal environments near ports (Pynaert and Speleers 2005) as it is showed in the studied port zones which reveal rises of $14 \%$ for $\mathrm{Cu}$.

Other anthropogenic pressure may come from river basin discharge. In fact, zone 018 which is located at the south exhibits high concentrations of metals, possibly due to the influence of the Segura river basin. 
As it is pointed out by Micó et al. (2006) pollutants from the industry around this basin have been discharged indiscriminately easing the bottom accumulation level.

In general, the southern areas of Valencia have lower concentrations of almost all metals than northern areas. Taking into account the significant statistical correlations among the metals studied, three groups of metals can be identified. The first group is formed by $\mathrm{Cr}, \mathrm{Ni}, \mathrm{As}$, and $\mathrm{Cd}$. All these metals were found in the same proportions in the sediments throughout the coastline. As Suresh et al. (2011) suggest, if the correlation coefficient between the metals is high, they have common sources, mutual dependence and identical behaviour during their transport, as occurred in $\mathrm{Cr}$ and $\mathrm{Ni}$, which may share lithogenic origin.

The second group is formed by $\mathrm{Cu}$ and $\mathrm{Zn}$, whose origin could be attributed to shipping and yachting activities, fishing harbours and fish-farming installations, which employ antifouling paints with active biocide zinc products, including zinc pyrithione, which is known to undergo transchelation with copper, depending on their relative concentrations in the water or sediment (Konstantinou et al. 2004). These biocides show a relatively high octanol/water partition coefficient, which could justify the enrichment of the antifouling compound in the sediment (Konstantinou et al. 2004).

Finally, $\mathrm{Pb}$ and $\mathrm{Hg}$ are joined, probably due to their lower concentration range and atmospheric origin. These aerosol-particles containing $\mathrm{Pb}$ are atmospherically transported (Cochran et al. 1998, Li et al. 2000) and may increase the sediment concentration. Although $\mathrm{Pb}$ has been removed from petrol, the historic contamination could affect the coastal sediments in many areas and its effects may last for decades. On the other hand, $\mathrm{Hg}$ can be released into the atmosphere by many processes, both natural and anthropogenic, with long residence times (about 0.5-2 yr) (Rada et al. 1989). The precipitation of this metal and oxidation processes can make it take on a water-soluble ionic form that may enter into aquatic systems. The atmospheric deposition of $\mathrm{Hg}$ (gas or particles) represents a major input of this element into the surface environment (Mason and Sheu 2002; Amos et al. 2012). Since the Hg species have a high affinity with particle surfaces and form insoluble precipitates, this metal is easily transported from the water column to the sediment (Kuwabara et al. 2003).

The evaluation of the sediments by the SQGs proposed by Long et al. 1995 and Macdonald et al. 1996, resulted in little or no adverse effects on aquatic organisms in the study area for $\mathrm{Ni}, \mathrm{Pb}, \mathrm{Cu}, \mathrm{Zn}$ and $\mathrm{Cd}$. However, for $\mathrm{Cr}$ and according to the SQGs of Long et al. (1995) there are 20 zones that have a $\mathrm{Cr}$ concentration within the ERL-ERM range, $(\mathrm{ERL}<[\mathrm{Cr}]<\mathrm{ERM})$, which indicates that adverse effects may 
occasionally occur in benthic organisms. This effect was not found when applying Macdonald et al.'s SQG since the Cr (TEL) value is 6.5- fold higher than ERL.

For As both SQGs applied yield 17 zones within the range (ERL $<[$ metal $]<$ ERM; TEL $<$ [metal $]<$ PEL). The Hg gives 2 zones within the range of $\mathrm{ERL}<[$ metal $]<$ ERM. Nevertheless, when other limits are applied (TEL-PEL) the number of zones increases, and zone 016 changes from "not expected effect" to "occasionally occurrence adverse effect". It is important to highlight that none of the metals studied exhibit concentration equal or higher to ERM or PEL values, suggesting that the whole stretch coastline studied evidence no potential risk to aquatic organism.

According to the MERMQ and mPELq Ecological Risk Indices, $75 \%$ of the zones in the first index and $42 \%$ of those in the second do not present any risk of toxicity or have a very low risk. This difference between the results of both indexes is due to the fact that the guide values for the mPELq index are lower (e.g. $56-60 \% \mathrm{Cr}, \mathrm{Cd}, \mathrm{Cu} ; 40-48 \% \mathrm{~Pb}$, As; and $33.9 \%$ in the case of $\mathrm{Zn}$, etc.), thus resulting in a greater number of areas with a higher probability of toxicity and a higher level of risk.

The results obtained from the RI index determine that the 23 out of 24 areas have low ecological risk, and only zone 017 have moderate ecological risk. The areas that show the highest values are the southern 016 and 017 and the port area 006, due to the Hg concentrations, since this index incorporates a toxic response factor for each metal. Since $\mathrm{Hg}$ is very toxic, those areas that have the highest $\mathrm{Hg}$ values also have the highest RI index values.

According to the results of the PLI and $\mathrm{mCd}$ indices, the 24 zones studied either do not have any metal contamination or the levels are very low. However, due to the values of these indexes in the northern areas 001 to 003 and the central areas 008 and 009, which are approaching the limit for adverse effects, it would be advisable to monitor these zones on a regular basis.

\section{Conclusions}

The most polluted areas were found in the northern areas ( 001,002 and 003$)$, in some central areas ( 008 , 009 and 010) and in two zones in the south of the Valencia coastline (017 and 018).

$\mathrm{Cr}, \mathrm{Ni}, \mathrm{As}$, and $\mathrm{Cd}$ were found in the same proportions in the sediments throughout the coastline, reflecting a similar origin (lithogenic, urban an industrial waste, wastewater...) and transport processes. 
The presence and correlation between $\mathrm{Cu}$ and $\mathrm{Zn}$ in the sediments was attributed to shipping and yachting activities and the use of antifouling paints with active biocide zinc products.

The conclusion drawn from the assessment, based on the application of guide levels with two SQGs, two Ecological Risk Indices and the three Background Enrichment Indices, is that the sediments in this area do not present contamination from the metals studied. The risk of sediment contamination is quite low and neither are there any adverse effects on aquatic organisms.

\section{Acknowledgements}

This research work has been supported by the Generalitat Valenciana as part of the studies involved in the Water Framework Directive.

\section{References}

Abrahim GMS, Parker RJ (2008) Assessment of heavy metal enrichment factor sand the degree of contamination in marine sediments from Tamaki Estuary, Auckland, New Zealand. Environ Monit Assess 136:227-238. https://doi.org/10.1007/s10661-007-9678-2

Adriano D (2001) Trace elements in terrestrial environments: biogeo- chemistry, bioavailability and risks of metals. Springer-Verlag, New York 866 pp

Alvarez-Guerra M, Viguri J, Casado-Martınez MC, Angel DelValls T (2007) Sediment quality assessment and dredged material manage- ment in Spain: part I, application of sediment quality guidelines in the Bay of Santander. Integr Environ Assess Manag 3:529-538

Amos HM, Jacob DJ, Holmes CD, Fisher JA, Wang Q, Yantosca RM, Corbitt ES, Galarneau E, Rutter A, Gustin MS, Steffen A, Schauer JJ, Graydon JA, St. Louis VL, Talbot RW, Edgerton ES, Zhang Y, Sunderland EM (2012) Gas-particle partitioning of atmospheric Hg (II) and its effect on global mercury deposition. Atmos Chem Phys 12:591-603. https://doi.org/10.5194/acp-12-591-2012

APHA (2012) Standard methods for the examination of water and wastewater, 21th. American Public Health Association, American Water Works Association, Water Environment Federation, Washington Badri MA, Aston SR (1983) Observation on heavy metals geochemical associations in polluted and nonpolluted estuarine sediments. Environ Pollut (Ser B) 6:181-193

Barhoumi B, Jouili S, Derouiche A, Elbarhoumi A, Mahfoudhi G, Atyaoui A, Bouabdallah S, Touil S, Ridha Driss M (2017) Sediment baseline study of levels, distributions and potential eco- logical risks of heavy metals in Bahiret El Bibane Lagoon (Tunisia, southwestern Mediterranean Sea). GERF Bull Biosci $8: 1-14$

Caeiro S, Costa MH, Ramos TB, Fernandes F, Silveira N, Coimbra A, Medeiros G, Painho M (2005)

Assessing heavy metal contamination in Sado Estuary sediment, an index analysis approach. Ecol Indic 5: 151-169. https://doi.org/10.1016/j.ecolind.2005.02.001 
Casado-Martínez MC, Forja JM, DelValls TA (2009) A multivariate assessment of sediment contamination in dredged materials from Spanish ports. J Hazard Mater 163:1353-1359.

https://doi.org/10.1016/j.jhazmat.2008.07.106

Christophoridis C, Dedepsidis D, Fytianos K (2009) Occurrence and distribution of selected heavy metals in the surface sediments of Thermaikos Gulf, N. Greece. Assessment using pollution indicators. J Hazard Mater 168:1082-1091. https://doi.org/10.1016/j.jhazmat.2009.02.154

Cochran JK, Frignani M, Salamanca M, Bellucci LG, Guerzoni S (1998) Lead-210 as a tracer of atmospheric input of heavy metals in the northern Venice Lagoon. Mar Chem 62:15-29

Directive 2008/105/EC of the European Parliament and of the Council of 16 December 2008 on environmental quality standards in the field of water policy, amending and subsequently repealing Council Directives 82/176/EEC, 83/513/EEC, 84/156/EEC, 84/491/EEC, 86/280/EEC and amending Directive 2000/60/EC of the European Parliament and of the Council

Directive 2013/39/EU of the European Parliament and of the Council of 12 August 2013 amending Directives 2000/60/EC and 2008/105/ EC as regards priority substances in the field of water policy text with EEA relevance

Donze M, Nieuwendijk C, Boxtel A, Quaak M (1990) Shaping the envi- ronment: aquatic pollution and dredging in the European communi- ty. Delwel Publishers, Hague 184 pp

EPA Method 3051A (2007) Microwave assisted acid digestion of sediments, sludges, soils, and oils. Washington, DC. https://www.epa. gov/sites/production/files/2015-12/documents/3051a.pdf. Accessed May 2017

Facchinelli A, Sacchi E, Mallen L (2001) Multivariate statistical and GIS- based approach to identify heavy metal sources in soils. Environ Pollut 114:313-324. https://doi.org/10.1016/S0269-7491(00)002438

Förstner U, Wittmann GT (1981) Metal pollution in the aquatic environment. Springer-Verlag, London Gao X, Chen CTA (2012) Heavy metal pollution status in surface sediments of the coastal Bohai Bay. Water Res 46:1901-1911. https:// doi.org/10.1016/j.watres.2012.01.007

GVA (2009) IMPRESS Document. Artícle 5 of the Water Framework Directive

Hakanson L (1980) An ecological risk index for aquatic pollution control, a sedimentological approach. Water Res 14:975-1001

Hosono T, Su CC, Siringan F, Amano A, Onodera S (2010) Effects of environmental regulations on heavy metal pollution decline in core sediments from Manila Bay. Mar Pollut Bull 60:780-785. https:// doi.org/10.1016/j.marpolbul.2010.03.005

Ip CCM, Li XD, Zhang G, Wai OWH, Li YS (2007) Trace metal distribution in sediments of the Pearl River Estuary and the surrounding coastal area, South China. Environ Pollut 147:311-323. https://doi. org/10.1016/j.envpol.2006.06.028 
Johnston EL, Roberts DA (2009) Contaminants reduce the richness and evenness of marine communities: a review and meta-analysis. Environ Pollut 157(6):1745-1752. https://doi.org/10.1016/j. envpol.2009.02.017

Konstantinou IK, Albanis TA (2004) Worldwide occurrence and effects of antifouling paint booster biocides in the aquatic environment: a review. Environ Int 30:235-248. https://doi.org/10.1016/S01604120(03)00176-4

Kuwabara JS, Alpers CN, Marvin-Di Pasquale M, Topping BR, Carter JL, Stewart AR, Fend SV, Parchaso F, Moon GE, Krabbenhoft DP (2003) Sediment-water interactions affecting dissolved-mercury dis- tributions in Camp Far West Reservoir, California. Publications of the US Geological Survey 53. http://digitalcommons.unl.edu/ usgspubs/53. Accessed Feb 2018

Leivouri M (1998) Heavy metal contamination in surface sediments in the Gulf of Finland and comparison with the Gulf of Bothnia. Chemosphere 36(1):43-59

Li XD, Wai OWH, Li YS, Coles BJ, Ramsey MH, Thornton I (2000) Heavy metal distribution in sediment profiles of the Pearl River estuary, South China. Appl Geochem 15:567-581

Li F, Huang J, Zeng G, Yuan X, Li X, Liang J, Wang X, Tang X, Bai B (2013) Spatial risk assessment and sources identification of heavy metals in surface sediments from the Dongting Lake, Middle China. J Geochem Explor 132:75-83. https://doi.org/10.1016/j.gexplo.2013.05.007

Long ER, MacDonald DD, Smith SL, Calder FD (1995) Incidence of adverse biological effects within ranges of chemical concentrations in marine and estuarine sediments. Environ Manag 19:81-97

Long ER, Field LJ, Macdonald DD (1998) Predicting toxicity in marine sediments with numerical sediment quality guidelines. Environ Toxicol Chem 17(4):714-727

Long ER, MacDonald DD, Severn CG, Hong CB (2000) Classifying the probabilities of acute toxicity in marine sediments with empirically derived sediment quality guidelines. Environ Toxicol Chem 19: 25982601

López P (1986) Composición del sedimento en sistemas acuáticos del litoral Mediterráneo Español. Limnética 2:11-18

Loska K, Wiechula D (2003) Application of principal component analysis for the estimation of source of heavy metal contamination in surface sediments from the Rybnik Reservoir. Chemosphere 51: 723-733. https://doi.org/10.1016/S0045-6535(03)00187-5

Luoma SN (1990) Processes affecting metal concentrations in estuarine and coastal marine sediments. In: Furness RW, Rainbow PS (eds) Heavy metals in the marine environment. CRC Press, Boca Raton, pp $51-66$

Macdonald DD, Carr RS, Calder FD, Long ER, Ingersoll CG (1996) Development and evaluation of sediment quality guidelines for Florida coastal waters. Ecotoxicology 5:253-278

Mason RP, Sheu GR (2002) Role of the ocean in the global mercury cycle. Glob Biogeochem Cycles 16(4):1-14. https://doi.org/10.1029/2001GB001440 
Micó C, Peris M, Sánchez J, Recatalá L (2006) Heavy metal content of agricultural soils in a Mediterranean semiarid area: the Segura River Valley (Alicante, Spain). Span J Agric Res 4(4):363-372 Palanques A, Díaz JI (1990) Contaminación de metales pesados en los sedimentos superficiales de la plataforma continental de Barcelona (Mediterráneo Noroccidental). Rev Soc Geol Esp 3(3-4):357-371 Parks R, Donnier-Marechal M, Frickers P, Turner A, Readman J (2010) Antifouling biocides in discarded marine paint particles. Mar Pollut Bull 60:1226-1230. https://doi.org/10.1016/j.marpolbul.2010.03.022 Pejman A, Bidhendi GN, Ardestani M, Mohsen Saeedi M, Akbar Baghvand A (2015) A new index for assessing heavy metals con- tamination in sediments: a case study. Ecol Indic 58:365-373. https://doi.org/10.1016/j.ecolind.2015.06.012

PRTR-España (2016) Spanish Register of Emissions and Pollutant Sources. http://www.prtr-es.es/. Accessed December 2017

Pynaert K, Speleers L (2005) Development of an integrated approach for the removal of tributyltin (TBT) from waterways and harbours: pre- vention, treatment and reuse of TBT contaminated sediments. Report by the Environmental Research Center, Hofstade-Aalst, Belgium, 52 pp Rada RG, Wiener JG, Winfrey MR, Powel DE (1989) Recent increase in atmospheric deposition of mercury to North Central Wiscosin lakes from sediment analyses. Arch Environ Contam Toxicol 18:175181. https://doi.org/10.1007/BF01056202

Rainbow PS (1995) Biomonitoring of heavy metal availability in the marine environment. Mar Pollut Bull 31(4-12):183-192. https:// doi.org/10.1016/0025-326X(95)00116-5

Reimann C, Filzmoser P, Garrett RG (2005) Background and threshold: critical comparison of methods of determination. Sci Total Environ 346(1-3):1-16. https://doi.org/10.1016/j.scitotenv.2004.11.023

Riba I, Casado-Martínez C, Forja JM, Del Vall A (2004) Sediment quality in the Atlantic coast of Spain. Environ Toxicol Chem 23:271-282

Romero I, Pachés M, Martínez-Guijarro R, Ferrer J (2013) Glophymed: an index to establish the ecological status for the Water Framework Directive based on phytoplankton in coastal waters. Mar Pollut Bull 75:218-223. https://doi.org/10.1016/j.marpolbul.2013.07.028

Sanchiz C, García-Carrascosa A, Pastor A (2000) Heavy metal contents in soft-bottom marine macrophytes and sediments along the Mediterranean coast of Spain. Mar Ecol 21(1):1-16

Suresh G, Ramasamy V, Meenakshisundaram V, Venkatachalapathy R, Ponnusamy V (2011) Influence of mineralogical and heavy metal composition on natural radionuclide contents in the river sediments. Appl Radiat Isot 69:1466-1474. https://doi.org/10.1016/j.apradiso.2011.05.020

Turekian KK, Wedepohl KH (1961) Distribution of the elements in some major units of the earth's crust. Geol Soc Am Bull 72:175-192

Turley PA, Fern RJ, Ritter JC (2000) Pyrithione as antifoulants: environ- mental chemistry and preliminary risk assessment. Biofouling 15: 175-182. https://doi.org/10.1080/08927010009386308 
Upadhyay AK, Gupta KK, Sircar JK (2006) Heavy metals in freshly deposited sediments of the river Subernarekha, India: an example of lithogenic and anthropogenic effects. Environ Geol 50:397-403. https://doi.org/10.1007/s00254-006-0218-0

Varol M (2011) Assessment of heavy metal contamination in sediments of the Tigris River (Turkey) using pollution indices and multivariate statistical techniques. J Hazard Mater 195:355-364.

https://doi.org/10.1016/j.jhazmat.2011.08.051

Wenning RJ, Ingersoll CG (eds) (2002) Executive summary of the SETAC Pellston workshop on use of sediment quality guidelines and related tools for the assessment of contaminated sediments. Society of Environmental Toxicology and Chemistry (SETAC), Pensacola

Yalcin MG, Tumuklu A, Sonmez M, Erdag DS (2010) Application of multivariate statistical approach to identify heavy metal sources in bottom soil of the Seyhan River (Adana), Turkey. Environ Monit Assess 164(1-4):311-322. https://doi.org/10.1007/s10661-009-0894-9

Zhang Z, Juying L, Mamat Z, QingFu Y (2016) Sources identification and pollution evaluation of heavy metals in the surface sediments of Bortala River, Northwest China. Ecotoxicol Environ Saf 126:94-101. https://doi.org/10.1016/j.ecoenv.2015.12.025

Zhao S, Feng C, Wang D, Tian C, Shen Z (2014) Relationship of metal enrichment with adverse biological effect in the Yangtze Estuary sediments: role of metal background values. Environ Sci Pollut Res 21:464-472. https://doi.org/10.1007/s11356-013-1856-X

Zhou J, Ma D, Pan J, Nie W, Wu K (2008) Application of multivariate statistical approach to identify heavy metal sources in sediment and waters: a case study in Yangzhong, China. Environ Geol 54:373380. https://doi.org/10.1007/s00254-007-0824-5 